\title{
Increasing the energy efficiency of the city- forming organizations of ferrous metallurgy
}

\author{
Kymbat Kunanbaeva ${ }^{1, *}$, Shakizada Niyazbekova ${ }^{2}$, Symbat Olzheken $^{1}$, and Sergey \\ Ryabichenko ${ }^{3}$ \\ ${ }^{1}$ Financial University under the Government of the Russian Federation, 49, Leningradskiy prospect, \\ 125993, Moscow, Russia \\ ${ }^{2}$ Moscow Witte University, 12, building 1, 2nd Kozhukhovsky proezd, 115432, Moscow, Russia \\ ${ }^{3}$ Moscow Region State University, Radio str., 10A, 105005, Moscow, Russia
}

\begin{abstract}
The issues of increasing the energy efficiency of the cityforming organizations of ferrous metallurgy are considered in this paper. Ferrous metallurgy is characterized by a high concentration of city-forming organizations, high social significance, and high energy intensity. The paper studies the issues of energy consumption of the city-forming organizations of ferrous metallurgy, highlights the directions for increasing the efficiency of the use of energy resources.
\end{abstract}

\section{Introduction}

Ferrous metallurgy is one of the leading sectors of the national economy, providing the development of related industries: machine-tool industry, motor vehicle industry, mechanical engineering, construction, etc. The development of ferrous metallurgy is caused by the presence of large deposits of iron ore, since Russia ranks third in the world in terms of iron ore reserves, after Australia and Brazil. Nowadays, the explored reserves of iron ore amount to about 25 billion tons [1].

Global trends in the development of ferrous metallurgy are characterized by development despite the impact of the pandemic. In January-December 2020, steel production increased by $3.4 \%$. Chinese steelmakers are encouraging investment to avoid declining production. Since 2016, China has significantly increased the introduction of new production facilities. As a result, the total capacity has approached 1.2 billion tons per year. In general, steel production is projected to grow by $4.7 \%$ for the period up to 2022 [2].

At the end of 2019, the Russian ferrous metals market reduced steel production by $0.6 \%$. In global production, the share of Russian steel was about $4 \%$, ranking fifth in the world after China, India, Japan, and the United States. January-September 2020 is characterized by a decrease of $2.9 \%$. In general, by the end of 2020, the Ministry of Economic Development of the Russian Federation predicts a 3\% decrease in steel production in comparable prices [2]. An increase in capital expenditures for the expansion and modernization of production facilities is forecasted for Russian companies as well. Nowadays, large Russian steel producers have presented updated development strategies

\footnotetext{
* Corresponding author: kunanbaeva_kymbat@mail.ru
} 
for the period up to 2023, including large investment projects [2]. The implementation of these projects should contribute to the resumption of growth in steel production from 2021.

The development of ferrous metallurgy in Russia is based on large vertically and horizontally integrated companies, which account for more than $93 \%$ of all manufactured products: Severstal PJSC; EVRAZ; Novolipetsk Metallurgical Plant OJSC; Magnitogorsk Iron and Steel Works PJSC; Metalloinvest PJSC; Mechel OJSC [1].

The structure-forming role of the Russian metallurgy lies in the fact that more than $70 \%$ of enterprises are city-forming organizations that perform the most important social functions, providing employment for single-industry municipalities, replenishing the budget, and improving the city's infrastructure.

Considering the technological features of ferrous metallurgy enterprises, it should be noted that they are characterized by high energy intensity. The share of the cost of fuel and energy resources in the total plant costs of manufacturing products is more than $30 \%$. The largest consumers of fuel in production are blast furnace and rolling production. Energyintensive industries include electric steel-making plants, oxygen plants, and the main consumers of heat are coke production [3].

Thus, ferrous metallurgy is the most important system-forming branch of the national economy with a high energy intensity. It also plays an important role in socio-economic development.

\section{Materials and Methods}

The high energy intensity of the city-forming organizations of ferrous metallurgy, together with the constant growth of prices for fuel and energy resources, puts the issues of improving energy efficiency in one of the first places. In this industry, the energy saving potential reaches $30 \%$ [3].

Nowadays, ferrous metallurgy plays a leading role in the formation of macro-indicators [3]:

- export-oriented industry, about $60 \%$ of rolled products are sent to foreign markets;

- ferrous metallurgy products occupy a significant share in the total volume of industrial products;

- the metallurgical industry functions in the system of global economic relations, and the development trends of the industry determine the development of related industries. The consumption of ferrous metallurgy products is provided through the motor vehicle industry, mechanical engineering, construction, oil and gas production, construction of oil and gas trunk pipelines, and pipe production.

The social role of the city-forming organizations of ferrous metallurgy is expressed in the following:

- ensuring employment of the population;

- receipt of tax deductions;

- maintaining the functioning of social infrastructure in the regions of presence;

- formation of incomes for a significant part of the working-age population;

- ensuring the solution of complex social problems of multifunctional settlements.

Thus, the city-forming organizations of ferrous metallurgy constitute the basis for the development of industrial and socio-economic development.

In ferrous metallurgy, the largest consumers of fuel are blast furnace and rolling mills. Energy-intensive industries include electric steel-making plants, oxygen plants, and the main consumers of heat are coke production [3]. Energy management as a complex system includes optimization of the work of each element and taking into account their influence on the whole process. This is especially true for objects under reconstruction and design. 
The potential for energy saving is especially relevant given the high moral and physical wear of the equipment of ferrous metallurgy enterprises. There is also a significant irregularity in the operation of metallurgical plants [3]. These factors, together with the issues of accounting and control over the consumption of fuel and energy resources, affect the occurrence of irrational losses of resources. Reducing irrational losses is the basis for reducing production costs and increasing the competitiveness of metal products.

In production activities, the city-forming organizations of ferrous metallurgy use various non-renewable types of energy resources (coal, coke products, natural gas, motor fuel, fuel oil). The share of energy consumption in the prime cost of ferrous metallurgy products is about $25 \%$, in nonferrous metallurgy - about $20 \%$ [4]. Nowadays, city-forming organizations strive to reduce the energy intensity of products by introducing more energy efficient technologies. Analysis of complex programs to improve energy efficiency makes it possible to single out the following key areas:

- use of secondary energy resources;

- $\quad$ automated control and accounting for the use of energy resources, including on the basis of digitalization;

- $\quad$ reduction in the share of purchased energy resources;

- $\quad$ introduction of energy saving technologies.

To study the issues of increasing energy efficiency, the following city-forming organizations of ferrous metallurgy were studied:

- Metalloinvest PJSC (Ural Steel OJSC);

- Severstal PJSC (CherMK OJSC);

- Magnitogorsk Iron and Steel Works PJSC.

Metalloinvest is a world leader in the production of commercial hot briquetted iron (HBI), a leading manufacturer and supplier of iron ore and metallized products, and one of the regional producers of high quality steel [13]. In 2019, the Metalloinvest Group saw a decrease in energy consumption due to the implementation of the energy efficiency program, which amounted to $0.7 \%$ compared to 2018 . Fuel consumption by type of fuel and electricity consumption by organizations are presented in Table 1.

Table 1. Fuel consumption by fuel type within the organization, 2017-2019. Source: [5].

\begin{tabular}{|c|c|c|c|c|}
\hline Fuel type & $\mathbf{2 0 1 7}$ & $\mathbf{2 0 1 8}$ & $\mathbf{2 0 1 9}$ & Change 2019/2018 (\%) \\
\hline Coal & 50321 & 42525 & 45185 & $6.3 \%$ \\
\hline Fuel oil & 88 & 88 & 79 & $-10.2 \%$ \\
\hline Natural gas & 134493 & 143871 & 139408 & $-3.1 \%$ \\
\hline Diesel fuel & 3165 & 3341 & 3485 & $4.3 \%$ \\
\hline Total & 188067 & 179825 & 188157 & $-0.9 \%$ \\
\hline
\end{tabular}

Magnitogorsk Iron and Steel Works PJSC is one of the world's largest steel producers and holds a leading position among Russian ferrous metallurgy enterprises. Energy efficiency issues are determined by the Energy Policy of the company. The enterprise purchases such resources as coking coal, thermal coal, natural gas, and electricity. The facility generates such resources as electricity, heat, steam, compressed air, and air separation products. Consumption and energy intensity indicators are presented in Table 2 . 
Table 2. The share of types of non-renewable energy sources in the fuel consumption of Magnitogorsk Iron and Steel Works PJSC, 2018-2019 (\%). Source: [6].

\begin{tabular}{|c|c|c|}
\hline Fuel type & $\mathbf{2 0 1 8}$ & $\mathbf{2 0 1 9}$ \\
\hline Coking coal & $55.82 \%$ & $55.69 \%$ \\
\hline Natural gas & $43.95 \%$ & $44.16 \%$ \\
\hline Thermal coal & $0.23 \%$ & $0.15 \%$ \\
\hline Total & $100 \%$ & $100 \%$ \\
\hline
\end{tabular}

Severstal PJSC. A vertically integrated mining and metallurgical company with major assets in Russia and abroad, Severstal PJSC is a supplier of high-quality rolled metal and steel pipes for the construction, mechanical engineering, motor vehicle and oil and gas industries, as well as a manufacturer of iron ore and coking coal [7]. Energy efficiency issues are being implemented in the company as part of the Comprehensive Energy Saving Program.

The needs of the Cherepovets Metallurgical Plant (CherMK) in energy resources are provided by a combined heat and power plant - a steam-air station (CHPP-SAS) and a combined heat and power plant - an electric air-blown station (CHPP-EAS 2). The structure of the fuel used at CherMK is presented in Table 9.

Table 3. Volume of used fuel, 2018-2019. Source: [7].

\begin{tabular}{|c|c|c|c|}
\hline Fuel type & 2018 & 2019 & $2019 / 2018, \%$ \\
\hline Blast furnace gas (million $\mathrm{m}^{3}$ ) & 12328 & 12157 & $98.6 \%$ \\
\hline Coke oven gas (million $\mathrm{m}^{3}$ ) & 1972 & 2184 & $110.7 \%$ \\
\hline Natural gas $\left(\right.$ million $\left.\mathrm{m}^{3}\right)$ & 2541 & 2389 & $94.01 \%$ \\
\hline
\end{tabular}

The decrease in natural gas consumption was caused by a change in the composition of raw materials in blast furnace production, a decrease in electricity generation, and an increase in the yield of coke oven gas. The overhaul of the turbine generator made it possible to reduce the consumption of blast furnace gas compared to 2018. The exit from the reconstruction of the coke oven battery contributed to the growth of coke oven gas consumption.

\section{Results}

Climatic conditions contributed to Metalloinvest's decline in natural gas consumption, since there was a warm winter in the central part of Russia, and in this regard, boiler plants were not working at full capacity. Diesel consumption was associated with an increase in the amount of stripping work performed by LGOK in an open pit to prepare production sites. A significant decrease in consumption for the Ural steel is caused by the introduction of a new FMF technology in electric steel-making furnaces with its replacement with natural gas [5]. The energy efficiency unit is managed by the Department of Energy. The company is implementing a Comprehensive program for increasing energy efficiency in production. Due to this program, by 2025 , it is planned to reduce energy resources by $5 \%$, electricity consumption by $8 \%$, gas by $8 \%$, fuels and lubricants by $50 \%$.

Coking coal and natural gas prevail in the structure of energy resources consumption by Magnitogorsk Iron and Steel Works PJSC. The company, in addition to the energy produced at its own power plants, buys energy, since its own generating sets are not enough. In 2019, the volume of purchased energy decreased due to the commissioning of a new turbine generator instead of the old one. This allowed the company to increase its own electricity generation and replace part of the purchased one.

In general, electricity consumption at the Cherepovets Metallurgical Plant decreased by $0.3 \%$, the share of its own electricity in the total consumption is $75.1 \%$. Electricity 
consumption at the company's enterprises (Karelsky Okatysh, Severstal-metiz, Severstal Kanaty, Volgogradsky Branch, OSPAZ, Izhora Pipe Plant) has a downward trend.

\section{Conclusions}

As the experience of solving issues of increasing energy efficiency shows, companies are implementing comprehensive programs in this area, setting key indicators, creating information and analytical systems for managing energy resources, and reconstructing production sites.

To improve the efficiency of the use of energy resources in ferrous metallurgy, the following key areas can be identified:

- creation and implementation of new energy-saving technologies;

- reconstruction of turbine generators, introduction of modern equipment;

- use of low energy-consuming building materials;

- increasing the level of utilization of secondary resources;

- introduction of an automated system for accounting and control over the consumption of energy resources.

It is also necessary to note the importance of organizational measures to improve energy consumption, such as conducting an energy audit, the formation and implementation of a comprehensive energy saving program, technological and commercial accounting of energy consumption, the introduction of an incentive system for the rational use of energy resources, etc. In general, the reduction in energy consumption will help to increase the competitiveness of metallurgical enterprises.

\section{References}

1. Metallurgy.

Analytical

reference, https://spravochnik.rosmintrud.ru/storage/app/media/Metallupgiya_2019.pdf

2. Ferrous Metals Market Review - 2020 (Deloitte CIS Research Center, Moscow, 2020) https://www2.deloitte.com/content/dam/Deloitte/ru/Documents/researchcenter/Обзор\%20рынка\%20черной\%20металлургии\%202020.pdf

3. Energy saving in ferrous metallurgy, https://mec-energo.ru/2011-10-03-19-09-18

4. E.N. Letyagina, L.N. Pertseva, E.V. Belova, Economics and Entrepreneurship 8(1), 1111-1114 (2015)

5. Metalloinvest, https://www.metalloinvest.com

6. Sustainable Development Report of MMK PJSC for 2019 (Moscow) http://mmk.ru/upload/report_sustainable_development/ MMК_2019\%20Отчет \%20об \%20устойчивом \%20развитии_RUS.pdf

7. Report on corporate social responsibility and sustainability (Moscow) http://severcstal.ru

8. K.B. Kunanbaeva, Transformation of entrepreneurial activity: new technologies, efficiency, prospects (Moscow, Publishing and Trade Corporation "Dashkov and $\mathrm{K}^{\circ}$,, 2021)

9. N.Y. Ryazanova, A.V. Sharkova, N.E. Lobzhanidze et al., International Journal of Recent Technology and Engineering 8(1), 2691-2695 (2019) ISSN: 22773878

10. Y.V. Morozyuk, A.V. Sharkova, I.A. Merkulina, O.N. Vasilyeva, Journal of Environmental Management and Tourism 8.3(19), 507-515 (2017) DOI: 10.14505/jemt.v8.3(19).02 
11. I.A. Markina, A.V. Sharkova, M.Y. Barna, International Journal of Entrepreneurship 22(3), 13 (2018) ISSN: 10999264

12. L. Akhmetshina, A. Mottaeva, E3S Web of Conferences 210, 13034 (2020) https://doi.org/10.1051/e3sconf/202021013034

13. L. Akhmetshina, A. Mussina, S. Izmaylova, IOP Conf. Series: Earth and Environmental Science 403, 012168 (2019) doi:10.1088/1755-1315/403/1/012168

14. T. Kreydenko, M. Chernyaev, E. Grigorieva, A. Korenevskaya, International Journal of Energy Economics and Policy 10(2), 504-511 (2020) DOI: 10.32479/ijeep. 9083

15. A. Rementsov, N. Lebedeva, O. Kirichenko, E3S Web of Conferences 164 (2020) DOI: $10.1051 / \mathrm{e} 3$ sconf/202016410039 